Article

\title{
Analysis of HBV Genomes Integrated into the Genomes of Human Hepatoma PLC/PRF/5 Cells by HBV Sequence Capture-Based Next-Generation Sequencing
}

\author{
Tomotaka Ishii ${ }^{1}$, Akinori Tamura ${ }^{1}$, Toshikatsu Shibata ${ }^{1}$, Kazumichi Kuroda ${ }^{1}$, \\ Tatsuo Kanda ${ }^{1, *(\mathbb{D}}$, Masaya Sugiyama ${ }^{2} \mathbb{D}$, Masashi Mizokami ${ }^{2}$ and Mitsuhiko Moriyama ${ }^{1}$ \\ 1 Division of Gastroenterology and Hepatology, Department of Medicine, Nihon University School of Medicine, \\ 30-1 Oyaguchi-kamicho, Itabashi-ku, Tokyo 173-8610, Japan; ishii.tomotaka@nihon-u.ac.jp (T.I.); \\ tamuraakinori0306@yahoo.co.jp (A.T.); toshimei@gmail.com (T.S.); kuroda.kazumichi@nihon-u.ac.jp (K.K.); \\ moriyama.mitsuhiko@nihon-u.ac.jp (M.M.) \\ 2 Genome Medical Science Project, National Center for Global Health and Medicine, Ichikawa 272-8516, Japan; \\ msugiyama@hosp.ncgm.go.jp (M.S.); mizokami0810@gmail.com (M.M.) \\ * Correspondence: kanda.tatsuo@nihon-u.ac.jp; Tel.: +81-3-3972-8111; Fax: +81-3-3956-8496
}

Received: 25 May 2020; Accepted: 16 June 2020; Published: 18 June 2020

check for updates

\begin{abstract}
Hepatitis B virus (HBV) infection is a leading cause of hepatocellular carcinoma (HCC) worldwide. The integration of HBV genomic DNA into the host genome occurs randomly, early after infection, and is associated with hepatocarcinogenesis in HBV-infected patients. Therefore, it is important to analyze HBV genome integration. We analyzed HBV genome integration in human hepatoma PLC/PRF/5 cells by HBV sequence capture-based next-generation sequencing (NGS) methods. We confirmed the results by using Sanger sequencing methods. We observed that HBV genotype $\mathrm{A}$ is integrated into the genome of PLC/PRF/5 cells. HBV sequence capture-based NGS is useful for the analysis of HBV genome integrants and their locations in the human genome. Among the HBV genome integrants, we performed functional analysis and demonstrated the automatic expression of some HBV proteins encoded by HBV integrants from chromosomes 3 and 11 in Huh7 cells transfected with these DNA sequences. HBV sequence capture-based NGS may be a useful tool for the assessment of HBV genome integration into the human genome in clinical samples and suggests new strategies for hepatocarcinogenesis in HBV infection.
\end{abstract}

Keywords: chromosome; HBV; HCC; hepatocarcinogenesis; Huh7; integration; next-generation sequencing; PLC/PRF/5; transfection

\section{Introduction}

Hepatitis B virus (HBV) infection occasionally induces hepatocellular carcinoma (HCC) through direct and indirect mechanisms and is an important cause of morbidity and mortality worldwide. HBV is a partially double-stranded DNA hepatotropic virus of $\sim 3.2 \mathrm{~kb}$ in length. The HBV DNA sequence consists of four open reading frames encoding the surface (HBsAg), core (HBcAg), polymerase, and $X(\mathrm{HBx})$ proteins $[1,2]$.

Soon after HBV infection, HBV DNA is converted into a covalently closed circular DNA molecule (HBV cccDNA) in the nucleus of HBV-infected cells as a stable episomal template [3]. HBV cccDNA is responsible for the chronic persistent $\mathrm{HBV}$ infection of hepatocytes. On the other hand, the integration of HBV DNA into the host genome occurs randomly, early after infection, and seems to continue [4-8]. Although the frequent observation of somatic integration of HBV DNA suggests a possible benefit for HBV 
replication, the mechanism of integration, its functions, and the clinical impact on hepatocarcinogenesis remain largely unknown $[9,10]$.

Next-generation sequencing (NGS) has been applied in various fields of virology and cancer research [6,7]. However, the low abundance of viral integration occasionally prevents viral identification. Specific target-sequence capture-based NGS has been developed as a method for detecting low levels of virus particles [11]. After fragments with HBV sequence were enriched by a set of HBV probes, high-throughput sequencing could detect the location of HBV integration breakpoints in the HCC genome [12]. Capture sequencing methods have higher sensitivity and efficiently detect sequences with low costs, compared to conventional methods [12,13].

In this report, we analyze HBV genome integration in human hepatoma PLC/PRF/5 cells [14] by more sensitive HBV sequence capture-based NGS methods. We constructed an HBV genome sequence and determined the HBV genotype (GT) in human hepatoma PLC/PRF/5 cells. We also focus on the topical subject of HBV DNA integration, which is linked HCC progression. We reveal HBV DNA integrants and their locations in the human genome. HBV sequence capture-based NGS is a useful and powerful tool for the assessment of HBV genome integration.

\section{Materials and Methods}

\subsection{Cell Culture}

Human hepatoma PLC/PRF/5 and Huh7 cells were purchased from the Japanese Collection of Research Bioresources (JCRB) Cell Bank (Osaka, Japan) [14]. The cells were maintained in Dulbecco's modified Eagle's medium (DMEM, Sigma-Aldrich, St. Louis, MO, USA) supplemented with $10 \%$ fetal bovine serum and $100 \mathrm{U} / \mathrm{mL}$ penicillin $/ 100 \mu \mathrm{g} / \mathrm{mL}$ streptomycin at $37^{\circ} \mathrm{C}$ in a $5 \% \mathrm{CO}_{2}$ atmosphere. We used PLC/PRF/5 cells within 5 passages in the present study.

\subsection{Cellular DNA Extraction and DNA Fragmentation}

Total DNA was isolated using a QIAamp DNA Mini Kit (Qiagen, Tokyo, Japan) according to the manufacturer's instructions. A total of $10 \mu \mathrm{g}$ DNA was fragmented using an E-200 ultrasonicator (Covaris, Unit H. Woburn, MA, USA) [15], and the size of the resulting DNA fragments was $~ 300 \mathrm{bp}$, which was confirmed by using an Agilent Bioanalyzer 2100 (Agilent Technologies, San Jose, CA, USA).

\subsection{Library Preparation and HBV Sequence Capture-Based Next-Generation Sequencing (NGS)}

After the generation of blunt-ended fragments, a sequence adapter was added with a TruSeq Nano DNA Sample Prep Kit (Illumina, San Diego, CA, USA). Target-capture sequencing on the Roche SeqCap platform was performed across HBV full genomes: GT-A (AP007263), GT-B (AB287327), and GT-C (AB368296). The DNA libraries from PLC/PRF/5 cells were captured using probes generated from these 3 HBV sequences by using SeqCap EZ Libraries (Roche NimbleGen, Tokyo, Japan).

HBV DNA-specific fragments were selectively collected with Invitrogen Dynabeads (Invitrogen, Carlsbad, CA, USA) and used as genome libraries. NGS of these libraries was performed by using a HiSeq 2000 (Illumina) system with a HiSeq PE Cluster Kit cBot (Invitrogen). Sequence data were processed using a standard pipeline in CLC Genomics Workbench (Qiagen). We focused on the accumulation of HBV-integrated sequences/fused/chimeric sequences and analyzed the sequences of the HBV and human genomes in each read by HBV sequence capture-based NGS. The integrated sequences of the $\mathrm{HBV}$ and human genomes with sequence reads $>100$ were analyzed.

HBV short genome sequences isolated at NGS were mapped to the reference sequence of HBV full genome GT-C (AB014378), resulting in the full-length HBV sequence (PLC-HBV) derived from PLC/PRF/5 cells being obtained.

All sequence reads have been submitted to the DNA Data Bank of Japan (DDBJ; temporary submission ID: SSUB015333). 


\subsection{Confirmation of HBV Genome Integration by Sanger Sequencing Methods}

PCR primers were designed at the following locations in the human genome (hg19): 131170441-131170444 and 131172081-131172105, 64808026-64808415 and 64808438-64808453, and 80063555-80063577 and 80065509-80065534 for HBV integrants in chromosomes 3, 11, and 17, respectively. PCR primers were also designed at the following locations, the human genome (hg19): 1296892-1296914 on chromosome 5 and 33662450-33662472 for translocation of chromosome $(5 ; 13)$. A total of $100 \mathrm{ng}$ DNA was amplified by PCR with KOD FX Neo (KFX-201, Toyobo, Osaka, Japan), according to the manufacturer's instructions.

The PCR products were cloned into the pCR-Blunt II-TOPO vector (Invitrogen). Sanger sequencing was performed with M13 forward and reverse primers using the BigDye Terminator v3.1 Cycle Sequencing Kit (Thermo Fisher Scientific, Tokyo, Japan) and an ABI 3730xl DNA Genetic Analyzer (Thermo Fisher Scientific), according to the manufacturer's instructions.

\subsection{Phylogenetic Analysis}

GENETYX version 10 (GENETEX Corp., Shibuya, Tokyo, Japan) was used to analyze the nucleotide sequences and perform phylogenetic tree analysis by neighbor-joining (NJ) methods. The statistical reliability of the phylogenetic trees was assessed using the bootstrap method on 10,000 times and the Kimura two-parameter model [16]. The accession numbers of sequences of various HBV GTs are indicated [17-21].

\subsection{Immunofluorescence Study}

HBV integrants from chromosomes 3 and 11 were cloned into the pCR-Blunt II-TOPO vector. Plasmids were transfected into Huh7 cells using Lipofectamine 2000 (Thermo Fisher Scientific). After $24 \mathrm{~h}$ of transfection, the cells were fixed with $4 \%$ paraformaldehyde (Gibco, Palo Alto, CA, USA) and incubated with an HBsAg-specific mouse monoclonal antibody (M3506, Dako, Carpinteria, CA, USA) at a dilution of 1:50, or HBV polymerase-specific mouse monoclonal antibody (2C8, sc-81590, Santa Cruz Biotechnology, Dallas, TX, USA) at a dilution of 1:50 for $1 \mathrm{~h}$. The cells were washed and incubated with anti-mouse Ig conjugated with an Alexa 594 secondary antibody (Invitrogen) at a dilution of 1:500 for $1 \mathrm{~h}$ at room temperature. Finally, the cells were washed and mounted for fluorescence microscopy (BIOREVIO BZ-9000, Keyence, Osaka, Japan). PLC/PRF/5 cells were used as control.

\section{Results}

\subsection{HBV DNA Sequence Derived from PLC/PRF/5 Cells}

Using HBV sequence capture-based NGS technology, we analyzed PLC/PRF/5 cells to reveal the HBV signature. HBV genome sequences were found in PLC/PRF/5 cells $(1,784,734$ reads out of $6,165,629$ reads, including the mitochondrial genome; see Table 1). We mapped these sequences onto a previously reported HBV sequence to obtain the full-length HBV sequence (PLC-HBV) derived from PLC/PRF/5 cells. PLC-HBV has been deposited in the DNA Data Bank of Japan (https://www.ddbj.nig. ac.jp/index-e.html; accessed on 28 March 2020 under accession number LC533934).

Table 1. The mapped reads and average coverage of hepatitis B virus (HBV) sequence capture-based next-generation sequencing in the present study.

\begin{tabular}{ccccccc}
\hline $\begin{array}{c}\text { Reference } \\
\text { Sequence }\end{array}$ & $\begin{array}{c}\text { Reference } \\
\text { Length }\end{array}$ & $\begin{array}{c}\text { Consensus } \\
\text { Length }\end{array}$ & $\begin{array}{c}\text { Total } \\
\text { Reads }\end{array}$ & $\begin{array}{c}\text { Single } \\
\text { Reads }\end{array}$ & $\begin{array}{c}\text { Reads in } \\
\text { Pairs }\end{array}$ & $\begin{array}{c}\text { Average } \\
\text { Coverage }\end{array}$ \\
\hline Chr. 1 & $2.49 \times 10^{8}$ & $1,545,531$ & 190,160 & 18,518 & 171,642 & 0.076008 \\
Chr. 2 & $2.43 \times 10^{8}$ & $1,344,151$ & 171,652 & 23,708 & 147,944 & 0.06996 \\
Chr. 3 & $1.98 \times 10^{8}$ & 985,756 & 134,430 & 19,312 & 115,118 & 0.067181 \\
Chr. 4 & $1.91 \times 10^{8}$ & 763,084 & 101,024 & 27,548 & 73,476 & 0.051384 \\
\hline
\end{tabular}


Table 1. Cont.

\begin{tabular}{ccccccc}
\hline $\begin{array}{c}\text { Reference } \\
\text { Sequence }\end{array}$ & $\begin{array}{c}\text { Reference } \\
\text { Length }\end{array}$ & $\begin{array}{c}\text { Consensus } \\
\text { Length }\end{array}$ & $\begin{array}{c}\text { Total } \\
\text { Reads }\end{array}$ & $\begin{array}{c}\text { Single } \\
\text { Reads }\end{array}$ & $\begin{array}{c}\text { Reads in } \\
\text { Pairs }\end{array}$ & $\begin{array}{c}\text { Average } \\
\text { Coverage }\end{array}$ \\
\hline Chr. 5 & $1.81 \times 10^{8}$ & 878,501 & 107,805 & 12,905 & 94,900 & 0.059238 \\
Chr. 6 & $1.71 \times 10^{8}$ & 978,370 & 143,424 & 13,186 & 130,238 & 0.083435 \\
Chr. 7 & $1.59 \times 10^{8}$ & $1,044,242$ & 136,171 & 13,449 & 122,722 & 0.085094 \\
Chr. 8 & $1.46 \times 10^{8}$ & 762,738 & 93,417 & 14,827 & 78,590 & 0.063299 \\
Chr. 9 & $1.41 \times 10^{8}$ & 599,234 & 65,741 & 9779 & 55,962 & 0.046138 \\
Chr. 10 & $1.36 \times 10^{8}$ & 769,055 & 110,259 & 27,795 & 82,464 & 0.079924 \\
Chr. 11 & $1.35 \times 10^{8}$ & 863,578 & $2,006,583$ & 126,939 & $1,879,644$ & 1.488781 \\
Chr. 12 & $1.34 \times 10^{8}$ & 736,429 & 115,138 & 21,172 & 93,966 & 0.084807 \\
Chr. 13 & $1.15 \times 10^{8}$ & 412,243 & 58,815 & 10,367 & 48,448 & 0.050038 \\
Chr. 14 & $1.07 \times 10^{8}$ & 455,809 & 53,252 & 4762 & 48,490 & 0.049338 \\
Chr. 15 & $1.03 \times 10^{8}$ & 490,545 & 348,653 & 17,775 & 330,878 & 0.338605 \\
Chr. 16 & $90,354,753$ & 563,883 & 114,919 & 48,517 & 66,402 & 0.122922 \\
Chr. 17 & $81,195,210$ & 524,407 & 106,805 & 25,583 & 81,222 & 0.128115 \\
Chr. 18 & $78,077,248$ & 394,380 & 52,617 & 7057 & 45,560 & 0.067025 \\
Chr. 19 & $59,128,983$ & 447,625 & 53,263 & 7119 & 46144 & 0.089332 \\
Chr. 20 & $63,025,520$ & 474,048 & 68,184 & 5948 & 62,236 & 0.107619 \\
Chr. 21 & $48,129,895$ & 254,738 & 32,117 & 4913 & 27,204 & 0.0658 \\
Chr. 22 & $51,304,566$ & 253,101 & 29,371 & 3049 & 26,322 & 0.05685 \\
Chr. X & $1.55 \times 108$ & 674,067 & 73,717 & 8491 & 65,226 & 0.047146 \\
Chr. Y & $59,373,566$ & 100,605 & 8838 & 8018 & 820 & 0.013505 \\
Chr. MT & 16,569 & 14,178 & 4540 & 172 & 4368 & 27.45869 \\
HBV & 3215 & 3213 & $1,784,734$ & 448,408 & $1,336,326$ & $53,732.01$ \\
\hline
\end{tabular}

Chr., chromosome (Hg19); MT, mitochondria; HBV, hepatitis B virus (AB014378) showing 90\% (2915/3220) homology to full-length HBV sequence (PLC-HBV).

Phylogenetic tree analysis by the neighbor-joining (NJ) method demonstrated that PLC-HBV belongs to HBV GT-A (Figure 1), in agreement with the production of subtype adw of HBsAg by $\mathrm{PLC} / \mathrm{PRF} / 5$ cells $[14,17]$ and the finding that the HBV genome sequences recovered from PLC/PRF/5 cells belong to HBV GT-A [18]. PLC-HBV shows nucleotide homology of 94\% (3054/3221), 90\% (2919/3220), and $91 \%(2932 / 3220)$ to the HBV sequences used for the generation of HBV capture probes in the present study (GT-A, HB-JI444AF (AP007263); GT-B, JPN Bj A53 (AB287327); GT-C C2, HBV-CH48-201w (AB368296), respectively) [22,23].

PLC/PRF/5 cells do not harbor an intracellular free HBV genome or infectious HBV virions in the conditioned medium [19,24-26]. Although there is one report showing that PLC/PRF/5 cells harbor full-length HBV genomes [20], the PLC-HBV genome is constructed from multiple partial HBV genome sequences in PLC/PRF/5 cells. Here, we demonstrate that HBV GT-A is integrated into the genome of PLC/PRF/5 cells.

\subsection{Analysis of HBV Genome Integrants and Their Locations in the Human Genome}

We focused on the accumulation of HBV-integrated sequences/fused/chimeric sequences and analyzed the sequences of the HBV and human genomes in each read by HBV sequence capture-based NGS. HBV-integrated sequences/fused/chimeric sequences consist of one derived from the host and the other from HBV. The results of the analysis for the integrated sequences of the HBV and human genomes with sequence reads $>100$ are shown in Table 2 .

Figure 2 shows the results regarding the integrated sequences of HBV and human genome chromosomes 3, 11, and 17, confirmed by Sanger sequencing methods. These results were different to some extent from those of NGS. Figure 2A presents the results for integrated HBV and human chromosome 3 sequences. Human genome chromosome 3 exhibits a 1637-bp deletion with the insertion of a partial 2623-bp HBV DNA sequence. The HBV regions included in this integrant are shown in Figure 2D. 


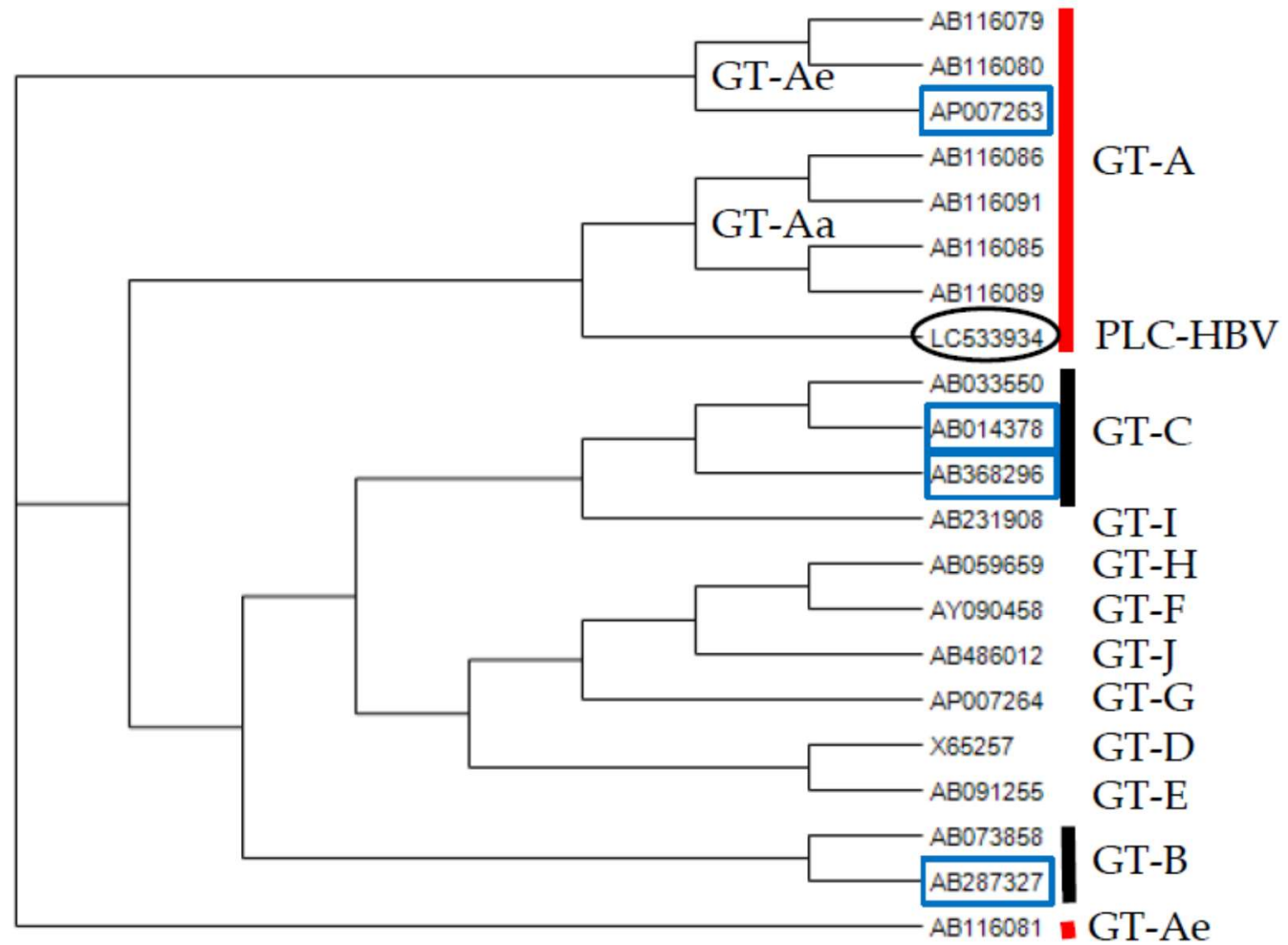

Figure 1. Phylogenetic tree for the hepatitis B virus (HBV) full-length genome obtained in the present study as determined by neighbor-joining (NJ) methods. Black circle, PLC-HBV (LC533934); blue square, reference sequences in the present study. GT-Ae, the original European genotype A; GT-Aa, the new African/Asian genotype A. The accession numbers of sequences of various HBV genotypes (GTs) are indicated [21-23,27,28].

Table 2. HBV and human genomes in PLC/PRF/5 cells determined by HBV sequence capture-based next-generation sequencing.

\begin{tabular}{|c|c|c|c|c|c|c|}
\hline $\begin{array}{c}\text { Human } \\
\text { Chromosome (Chr.) }\end{array}$ & $\begin{array}{c}\text { Human Junction } \\
\text { Nucleotide Position }\end{array}$ & $\begin{array}{l}\text { Gene } \\
\text { Name }\end{array}$ & $\begin{array}{l}\text { HBV Fragment } \\
\text { Start Position }\end{array}$ & $\begin{array}{l}\text { HBV Fragment } \\
\text { End Position }\end{array}$ & $\begin{array}{c}\text { HBV } \\
\text { Genome }\end{array}$ & $\begin{array}{c}\text { Number of } \\
\text { Total Reads * }\end{array}$ \\
\hline Chr.3 & 131170552 & NA & 1044 & 1406 & $P, S, X$ & 3673 \\
\hline Chr.3 & 131171957 & NA & 1415 & 1914 & $C, P, S, X$ & 3589 \\
\hline Chr.4 & 181507570 & NA & 96 & 432 & $\mathrm{P}, \mathrm{S}$ & 1548 \\
\hline Chr.4 & 181508764 & NA & 235 & 387 & $P, S$ & 4377 \\
\hline Chr.5 & 1297593 & NA & 1175 & 1364 & $P, S$ & 3680 \\
\hline Chr.11 & 64808432 & SAC3D1 & 2575 & 2851 & $P, S$ & 6616 \\
\hline Chr.12 & 110012332 & MVK & 692 & 1379 & $P, S, X$ & 10,130 \\
\hline Chr.13 & 33662251 & NA & 1897 & 2109 & $C, P, S$ & 4060 \\
\hline Chr.13 & 33662698 & NA & 783 & 1612 & $P, S, X$ & 1494 \\
\hline Chr.17 & 80063662 & CCDC57 & 428 & 2586 & $\mathrm{P}, \mathrm{S}$ & 7699 \\
\hline Chr.17 & 80065497 & CCDC57 & 2062 & 2420 & $C, P, S$ & 6918 \\
\hline
\end{tabular}

Chr., chromosome (Hg19); NA, not available; UNC5D, unc-5 netrin receptor D; SNX15, sorting nexin 15; SAC3D1, SAC3 domain-containing 1; MVK, mevalonate kinase; CCDC57, coiled-coil domain-containing 57; $\mathrm{HBV}$, hepatitis $\mathrm{B}$ virus; $\mathrm{C}$, core; $\mathrm{P}$, polymerase; $\mathrm{S}$, surface antigen; $\mathrm{X}, \mathrm{HBx}$; ${ }^{*}$, confirmed by $\mathrm{HBV}$ sequence capture-based next-generation sequencing.

Figure 2B shows the results regarding integrated HBV and human chromosome 11 sequences. Human genome chromosome 11 exhibits a 17-bp deletion with the insertion of a partial 1591-bp HBV DNA sequence. The HBV regions included in this integrant are shown in Figure 2D. The insertion point of human chromosome 11 is the intron of the SAC3 domain-containing 1 (SAC3D1) region. The SAC3D1 mRNA is significantly associated with the overall survival of patients with HCC (B Cox value, +0.540; HR (95\% CI), $1.717(0.179-3.00) ; p<0.0001)$. Higher expression of SAC3D1 mRNA 
in HCC is considered a high-risk factor associated with short survival [29]. SAC3D1 is associated with centrosome abnormalities, and SAC3D1 could be a prognostic marker for HCC recurrence after surgical treatment [30].

Figure 2C provides the results for integrated HBV and human chromosome 17 sequences. Human genome chromosome 17 harbors a 1932-bp deletion with the insertion of a partial 1699-bp HBV DNA sequence. The HBV regions included in this integrant are shown in Figure 2D. The insertion point of human chromosome 17 is the coiled-coil domain-containing 57 (CCDC57) coding region. It has been reported that CCDC57 is one of the genes targeted by the integration of human papillomavirus 16 (HPV 16) [31].

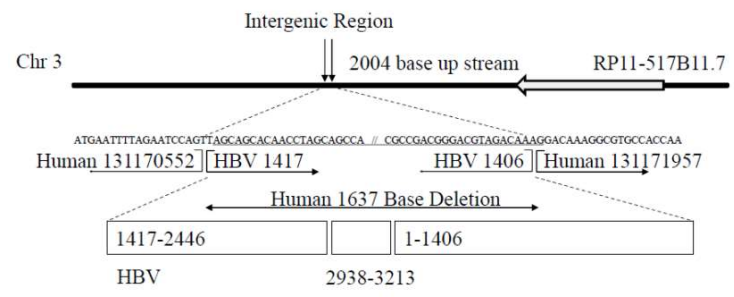

(A)

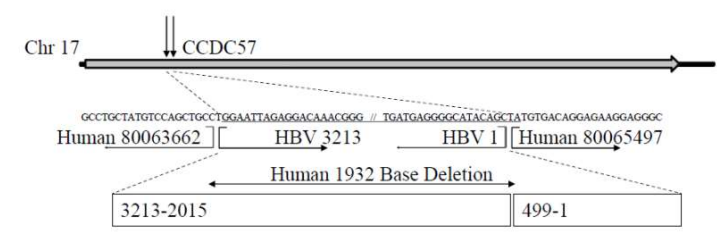

(C)

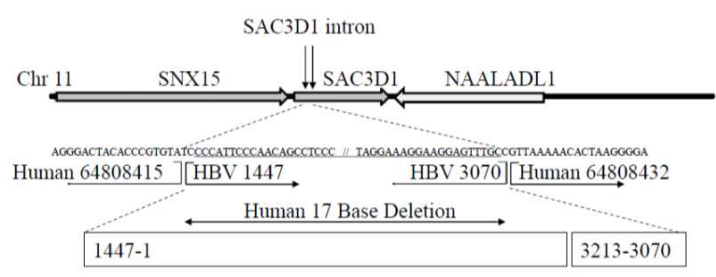

(B)

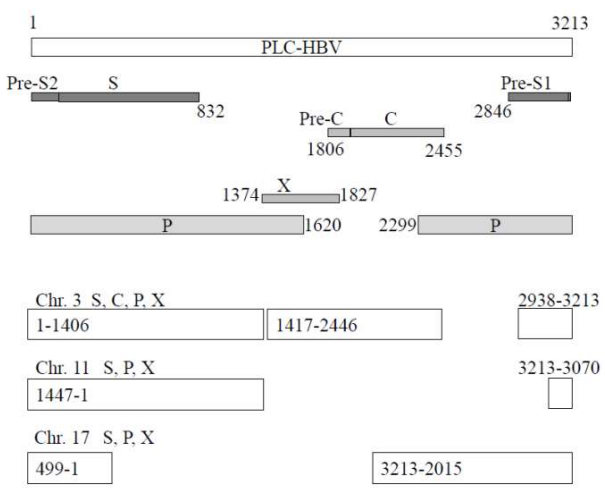

(D)

Figure 2. Results for integrated sequences of hepatitis B virus (HBV) and human genome chromosomes (Chrs) 3, 11, and 17 determined by Sanger sequencing. (A) Chr 3, (B) Chr 11, (C) Chr 17, deletion of human genome sequence including part of an exon, (D) summary of HBV integrants in PLC/PRF/5 cells confirmed by Sanger methods. SNX15, sorting nexin 15; SAC3D1, SAC3 domain-containing 1; NAALADL1, N-acetylated alpha-linked acidic dipeptidase such as 1; CCDC57, coiled-coil domaincontaining 57; S, surface antigen; $C$, core; $\mathrm{P}$, polymerase; $\mathrm{X}, \mathrm{HBx}$.

\subsection{Translocation of Chromosomes (5; 13) with HBV Integrants}

We also observed the translocation of chromosomes $(5 ; 13)$ with HBV genome integrants (Figure 3). The results confirmed by Sanger sequencing methods demonstrate that the insertion point in human chromosome 5 is 2409 bp upstream of the telomerase reverse transcriptase (TERT) gene, which is located near the TERT promoter region. The HBV regions included in this integrant are shown in Figure 3. The insertion point in human chromosome 13 is also $15021 \mathrm{bp}$ downstream of the StAR-related lipid transfer domain containing 13 (STARD13) genes (Figure 3). 

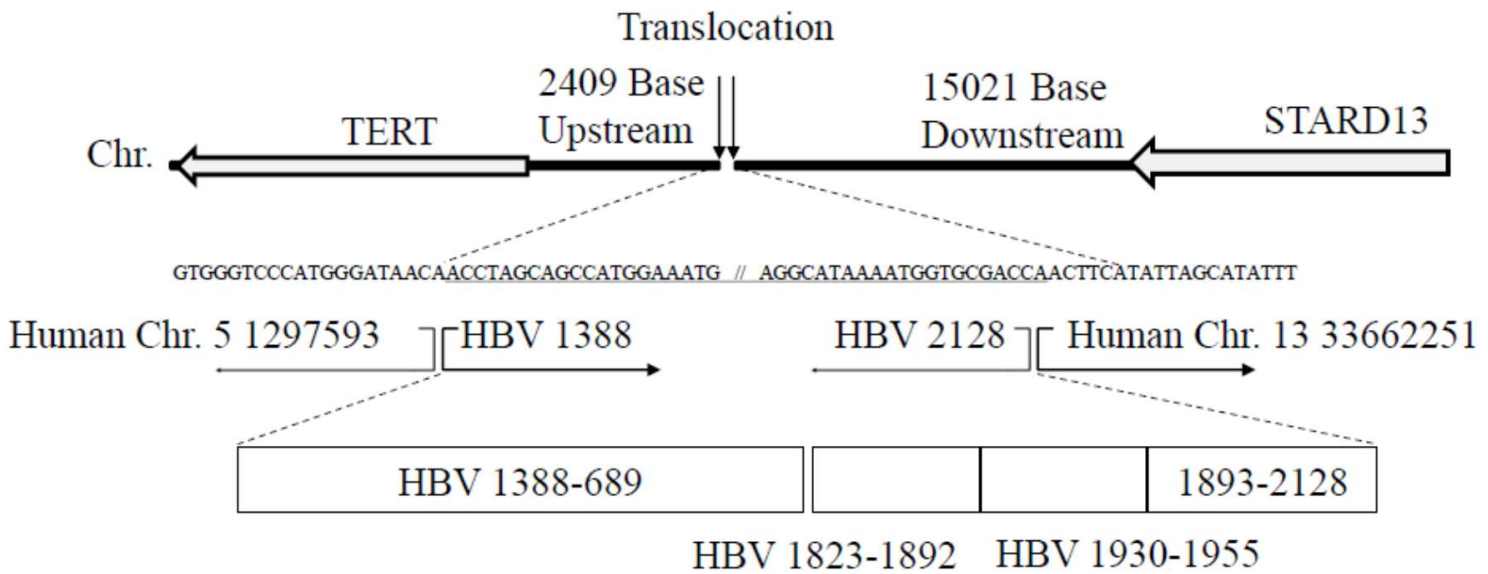

Figure 3. Translocation of chromosomes $(5 ; 13)$ with hepatitis B virus (HBV) integrants. The results were confirmed by Sanger sequencing methods. Chr, chromosome (Hg19); TERT, telomerase reverse transcriptase; STARD13, StAR-related lipid transfer domain containing 13 genes.

3.4. Automatic Expression of Proteins of HBV Integrants from Chromosomes 3 and 11, from the Vector without Any Promoter Sequences

To examine the function of HBV integrant DNA from chromosome 3 in Huh7 cells after $24 \mathrm{~h}$ of transfection, we examined the expression of each HBV protein by immunofluorescence analysis. Compared to the expression of HBV proteins in PLC/PRF/5 (Figure 4A), we observed higher expression of both HBsAg and HBV polymerase protein in HBV integrant DNA-transfected Huh7 cells (Figure 4B). We did not observe HBcAg or HBx protein expression in HBV integrant DNA-transfected Huh7 cells (data not shown).

After $24 \mathrm{~h}$ of transfection of the HBV integrant from chromosome 11 into Huh7 cells, we observed only HBsAg expression (Figure 4C). As the pCR-Blunt II-TOPO vector is a cloning vector and does not contain any promoters for the expression of coding proteins in mammalian cells, these integrants should automatically express the HBV-host fusion, HBsAg or HBV polymerase protein. No previous studies have shown polymerase expression in PLC/PRF/5 cells.

(A)
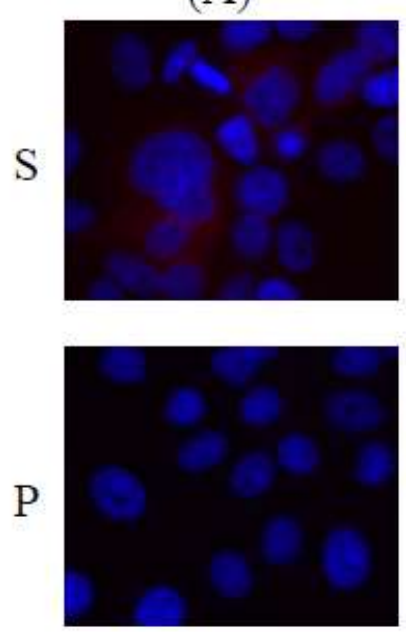

(B)
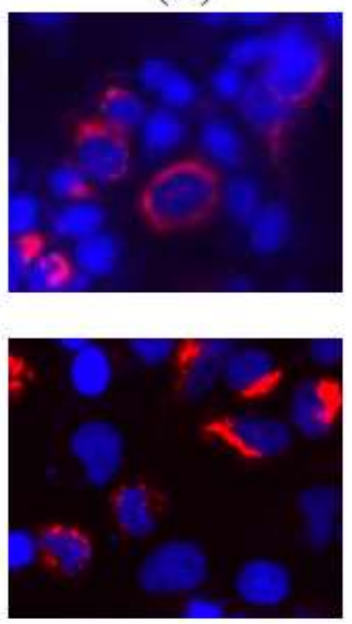

(C)

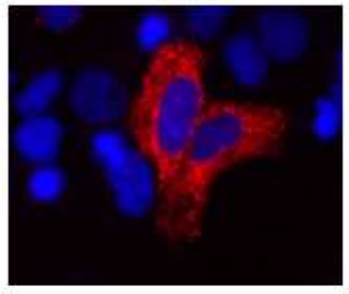

Figure 4. Automatic expression of proteins of $\mathrm{HBV}$ integrants from chromosomes 3 and 11. Representative images are shown (40×). Fluorescent immunostaining for HBsAg (S) and HBV polymerase (P) in PLC/PRF/5 cells (A), Huh7 cells transfected with the pCR-Blunt II-TOPO-HBV integrant from chromosome 3 (B), or Huh7 cells transfected with the pCR-Blunt II-TOPO-HBV integrant from chromosome 11 (C). 


\section{Discussion}

We observed that HBV GT-A is a major GT of HBV integrated into PLC/PRF/5 cells. HBV sequence capture-based NGS is useful for the analysis of HBV genome integrants and their locations in the human genome. Among these HBV genome integrants, we performed functional analysis and demonstrated the automatic expression of some HBV proteins of HBV integrants from chromosomes 3 and 11 in Huh7 cells transfected with these DNA sequences.

The integration of a viral genome could lead to the disruption of the function of the human genome [32-35]. The deregulation of key cellular genes by HBV integration, which may present a selective growth advantage to hepatocytes and result in hepatocarcinogenesis, is thought to occur through several distinctive mechanisms.

PLC/PRF/5 cells can produce HBsAg in the cell culture medium [14,19]. Edman et al. reported that the PLC/PRF/5 cell line contains at least six (four complete and two incomplete) HBV genomes integrated into high-molecular-weight host DNA [20]. Northern blot analysis demonstrated the presence of RNA transcripts specific for the surface antigen sequences of HBV DNA and the absence of detectable transcripts corresponding to the hepatitis B core antigen, supporting the results of the immunofluorescence analysis conducted in the present study (Figure 4).

A previous in situ hybridization study with an HBV DNA probe for metaphase chromosomes of the PLC/PRF/5 cell line followed by statistical analysis identified 3 integration sites, namely, 11q22, 15q22-q23 and 18q12 [36], and we also found partial HBV genomes in chromosomes other than 11, 15, and 18 (Table 1). It is possible that our methods are more sensitive and less error-prone.

HBV genome integration into exons and introns results in truncated proteins and decreased protein expression levels, respectively. We found HBV integrants in the intron of chromosome 3 (Figure 2A) and part of the exon of CCDC57 in chromosome 17 (Figure 2C). We also found HBV integrants in the exon of SAC3D1 in chromosome 11 (Figure 2B).

Monjardino et al. reported that a defective HBV DNA molecule (approx. 2.8 kilobase pairs) appears to be integrated in a head-to-tail tandem arrangement, and they proposed that such defective molecules may be involved in the induction of hepatocarcinogenesis by HBV [26].

HBV genome integration induces aberrant promoter function in the host genome. Figure 3 shows HBV genome integration in a region close to the TERT promoter. Telomerase activity, which restores the length of telomere repeat arrays, is frequently observed in various malignancies, including HCC. As TERT is a protooncogene, the integration of HBV could result in hepatocarcinogenesis through its amplification and/or overexpression [37]. We also measured TERT mRNA by real-time RT-PCR, but we did not see any difference in TERT mRNA among PLC/PRF/5, Huh7, and HepG2 cells.

STARD13/Deleted in Liver Cancer (DLC) proteins belong to the RhoGAP family, and this protein is more abundantly expressed in HCC tissue, in particular, in the association with inflammation background [38]. STARD13 is related to HCC growth and hepatocarcinogenesis [38-40], although there is a report that HCC-patients with higher STARD13 or Fas expression levels have longer overall survival [41]. The consequences of the detected HBV integration sites and the clinical consequences or integration impact on hepatocarcinogenesis are yet unclear.

Interestingly, the automatic expression of some proteins encoded by HBV integrants from chromosomes 3 and 11 was observed in Huh7 cells transfected with these DNA sequences. This phenomenon may be involved in hepatocarcinogenesis in patients infected with HBV. Chromosome $11 \mathrm{HBV}$ integrants did not code HBV full-length polymerase (Figure 2D). This may be the reason why we did not observe HBV polymerase protein in Huh7 cells transfected by chromosome $11 \mathrm{HBV}$ integrants (Figure 4C). Further studies, including the functional analysis of these mechanisms, are needed.

In the present study, we enhanced NGS using HBV-targeted sequence capture. Although metagenomic shotgun sequencing is an important tool for the characterization of viral populations, metagenomic shotgun sequencing occasionally lacks sensitivity and may yield insufficient data for detailed analysis [42,43]. A targeted sequence-capture panel enhances metagenomic shotgun sequencing [42,43]. As genetic libraries must be generated from samples with low concentrations of HBV DNA and a high content of 
nucleic acids from a host in many cases [44], HBV hybridization-based enrichment may be useful for improving the sensitivity of the detection of HBV genome integration in hepatocytes. However, it is difficult to demonstrate how many copies of HBV deletion/rearrangements exist per cell, and single-cell genome sequencing may be helpful in this case [45].

Characteristics of human hepatoma PLC/PRF/5 cells have been reported for 40 years [36,46-48], and several genome sequences in the present study were not reported in detail. Watanabe et al. extensively analyzed the characteristics of human hepatoma PLC/PRF/5 cells using other NGS strategies [49]. However, they did not report the translocation of chromosomes $(5 ; 13)$ with HBV integrants, which the present study has mentioned, suggesting that the HBV sequence capture-based NGS method is the more powerful and sensitive tool for the analysis of HBV integrants.

Characteristics of human hepatoma PLC/PRF/5 cells may not reflect those of human HCC samples. It may be useful to analyze the HBV integrants in human HCC samples by our methods, although there may be false-positives in their analysis and their impact when real clinical samples that contain high levels of circulating virus are used. A similar approach has already been used for the identification of HBV integration in the human genome of clinical samples [12]. Compared to the method reported by Li et al. [12], our method does not require special computational analysis. The limitation of our study is that we did not use clinical samples. Further study is needed.

\section{Conclusions}

The HBV replication mechanism and the mechanism of integration, its functions, and the clinical impact on hepatocarcinogenesis remain largely unknown. HBV sequence capture-based NGS is a useful and powerful tool for the assessment of HBV genome integration to explore HBV genome integrants and their locations in the human genome. Clinical impact on hepatocarcinogenesis and new treatment strategies can be provided through this method.

Author Contributions: Conceptualization, T.I., A.T., K.K., and M.M. (Mitsuhiko Moriyama); methodology, T.I., A.T., M.S., K.K., and M.M. (Mitsuhiko Moriyama); software, M.S., A.T., T.S., and K.K.; validation, M.S., A.T., T.S., and K.K.; formal analysis, M.S., A.T., T.S., and K.K.; investigation, T.I., M.S., A.T., T.S., and K.K.; resources, M.S., A.T., T.S., and K.K.; data curation, M.S., A.T., T.S., and K.K.; writing-original draft preparation, T.I., A.T., and T.K.; writing-review and editing, T.I. and T.K.; visualization, T.K.; supervision, M.M. (Masashi Mizokami); funding acquisition, M.M. (Mitsuhiko Moriyama); All authors have read and agreed to the published version of the manuscript.

Funding: This research was funded by a Nihon University Multidisciplinary Research Grant (15-009 to M.M. (Mitsuhiko Moriyama)).

Acknowledgments: The authors thank all staff members at the Nihon University School of Medicine, Itabashi Hospital, for the care provided.

Conflicts of Interest: The authors declare no conflict of interest.

\section{References}

1. Suzuki, K.; Uchida, T.; Shikata, T.; Moriyama, M.; Arakawa, Y.; Mizokami, M.; Mima, F. Expression of pre-S1, pre-S2, S and X peptides in relation to viral replication in livers with chronic hepatitis B. Liver 1990, 10, 355-364. [CrossRef] [PubMed]

2. Terada, T.; Moriyama, M.; Uchida, T.; Arakawa, Y. Nucleotide sequence of the precore/core gene and X gene of hepatitis B virus DNA in asymptomatic hepatitis B virus carriers who are negative for serum hepatitis B core antibody. Intervirology 2001, 44, 243-249. [CrossRef] [PubMed]

3. Yokosuka, O.; Omata, M.; Imazeki, F.; Ito, Y.; Okuda, K. Hepatitis B virus RNA transcripts and DNA in chronic liver disease. N. Engl. J. Med. 1986, 315, 1187-1192. [CrossRef] [PubMed]

4. Chauhan, R.; Churchill, N.D.; Mulrooney-Cousins, P.M.; Michalak, T.I. Initial sites of hepadnavirus integration into host genome in human hepatocytes and in the woodchuck model of hepatitis B-associated hepatocellular carcinoma. Oncogenesis 2017, 6, e317. [CrossRef] [PubMed] 
5. Tu, T.; Budzinska, M.A.; Vondran, F.W.R.; Shackel, N.A.; Urban, S. Hepatitis B Virus DNA Integration Occurs Early in the Viral Life Cycle in an In Vitro Infection Model via Sodium Taurocholate Cotransporting Polypeptide-Dependent Uptake of Enveloped Virus Particles. J. Virol. 2018, 92, e02007-e02017. [CrossRef] [PubMed]

6. Totoki, Y.; Tatsuno, K.; Covington, K.R.; Ueda, H.; Creighton, C.J.; Kato, M.; Tsuji, S.; Donehower, L.A.; Slagle, B.L.; Nakamura, H.; et al. Trans-ancestry mutational landscape of hepatocellular carcinoma genomes. Nat. Genet. 2014, 46, 1267-1273. [CrossRef] [PubMed]

7. Zucman-Rossi, J.; Villanueva, A.; Nault, J.C.; Llovet, J.M. Genetic Landscape and Biomarkers of Hepatocellular Carcinoma. Gastroenterology 2015, 149, 1226-1239.e4. [CrossRef] [PubMed]

8. Tatsuno, K.; Midorikawa, Y.; Takayama, T.; Yamamoto, S.; Nagae, G.; Moriyama, M.; Nakagawa, H.; Koike, K.; Moriya, K.; Aburatani, H. Impact of AAV2 and Hepatitis B Virus Integration Into Genome on Development of Hepatocellular Carcinoma in Patients with Prior Hepatitis B Virus Infection. Clin. Cancer Res. 2019, 25, 6217-6227. [CrossRef] [PubMed]

9. Sung, W.K.; Zheng, H.; Li, S.; Chen, R.; Liu, X.; Li, Y.; Lee, N.P.; Lee, W.H.; Ariyaratne, P.N.; Tennakoon, C.; et al. Genome-wide survey of recurrent HBV integration in hepatocellular carcinoma. Nat. Genet. 2012, 44, 765-769. [CrossRef] [PubMed]

10. Zhao, L.H.; Liu, X.; Yan, H.X.; Li, W.Y.; Zeng, X.; Yang, Y.; Zhao, J.; Liu, S.P.; Zhuang, X.H.; Lin, C.; et al. Genomic and oncogenic preference of HBV integration in hepatocellular carcinoma. Nat. Commun. 2016, 7, 12992. [CrossRef] [PubMed]

11. No, J.S.; Kim, W.K.; Cho, S.; Lee, S.H.; Kim, J.A.; Lee, D.; Song, D.H.; Gu, S.H.; Jeong, S.T.; Wiley, M.R.; et al. Comparison of targeted next-generation sequencing for whole-genome sequencing of Hantaan orthohantavirus in Apodemus agrarius lung tissues. Sci. Rep. 2019, 9, 16631. [CrossRef] [PubMed]

12. Li, W.; Zeng, X.; Lee, N.P.; Liu, X.; Chen, S.; Guo, B.; Yi, S.; Zhuang, X.; Chen, F.; Wang, G.; et al. HIVID: An efficient method to detect HBV integration using low coverage sequencing. Genomics 2013, 102, 338-344. [CrossRef] [PubMed]

13. Shukla, R.; Upton, K.R.; Muñoz-Lopez, M.; Gerhardt, D.J.; Fisher, M.E.; Nguyen, T.; Brennan, P.M.; Baillie, J.K.; Collino, A.; Ghisletti, S.; et al. Endogenous retrotransposition activates oncogenic pathways in hepatocellular carcinoma. Cell 2013, 153, 101-111. [CrossRef] [PubMed]

14. MacNab, G.M.; Alexander, J.J.; Lecatsas, G.; Bey, E.M.; Urbanowicz, J.M. Hepatitis B surface antigen produced by a human hepatoma cell line. Br. J. Cancer 1976, 34, 509-515. [CrossRef] [PubMed]

15. Poptsova, M.S.; Il'icheva, I.A.; Nechipurenko, D.Y.; Panchenko, L.A.; Khodikov, M.V.; Oparina, N.Y.; Polozov, R.V.; Nechipurenko, Y.D.; Grokhovsky, S.L. Non-random DNA fragmentation in next-generation sequencing. Sci. Rep. 2014, 4, 4532. [CrossRef] [PubMed]

16. Kimura, M.A. Simple Method for Estimating Evolutionary Rates of Base Substitutions Through Comparative Studies of Nucleotide Sequences. J. Mol. Evol. 1980, 16, 111-120. [CrossRef] [PubMed]

17. Yotsumoto, S.; Okamoto, H.; Tsuda, F.; Miyakawa, Y.; Mayumi, M. Subtyping hepatitis B virus DNA in free or integrated forms by amplification of the S-gene sequences by the polymerase chain reaction and single-track sequencing for adenine. J. Virol. Methods 1990, 28, 107-116. [CrossRef] [PubMed]

18. Freitas, N.; Cunha, C.; Menne, S.; Gudima, S.O. Envelope proteins derived from naturally integrated hepatitis B virus DNA support assembly and release of infectious hepatitis delta virus particles. J. Virol. 2014, 88, 5742-5754. [CrossRef] [PubMed]

19. Haga, Y.; Kanda, T.; Nakamoto, S.; Nakamura, M.; Sasaki, R.; Wu, S.; Yokosuka, O. Interferon induces interleukin 8 and bone marrow stromal cell antigen 2 expression, inhibiting the production of hepatitis B virus surface antigen from human hepatocytes. Biochem. Biophys. Res. Commun. 2017, 486, 858-863. [CrossRef] [PubMed]

20. Edman, J.C.; Gray, P.; Valenzuela, P.; Rall, L.B.; Rutter, W.J. Integration of hepatitis B virus sequences and their expression in a human hepatoma cell. Nature 1980, 286, 535-538. [CrossRef] [PubMed]

21. Sugauchi, F.; Kumada, H.; Acharya, S.A.; Shrestha, S.M.; Gamutan, M.T.A.; Khan, M.; Gish, R.G.; Tanaka, Y.; Kato, T.; Orito, E.; et al. Epidemiological and sequence differences between two subtypes (Ae and Aa) of hepatitis B virus genotype A. J. Gen. Virol. 2004, 85, 811-820. [CrossRef] [PubMed]

22. Shibayama, T.; Masuda, G.; Ajisawa, A.; Hiruma, K.; Tsuda, F.; Nishizawa, T.; Takahashi, M.; Okamoto, H. Characterization of seven genotypes (A to E, G and H) of hepatitis B virus recovered from Japanese patients infected with human immunodeficiency virus type 1. J. Med. Virol. 2005, 76, 24-32. [CrossRef] [PubMed] 
23. Sakamoto, T.; Tanaka, Y.; Simonetti, J.; Osiowy, C.; Borresen, M.L.; Koch, A.; Kurbanov, F.; Sugiyama, M.; Minuk, G.Y.; McMahon, B.J.; et al. Classification of hepatitis B virus genotype B into 2 major types based on characterization of a novel subgenotype in Arctic indigenous populations. J. Infect. Dis. 2007, 196, 1487-1492. [CrossRef]

24. Marion, P.L.; Salazar, F.H.; Alexander, J.J.; Robinson, W.S. State of hepatitis B viral DNA in a human hepatoma cell line. J. Virol. 1980, 33, 795-806. [CrossRef] [PubMed]

25. Daemer, R.J.; Feinstone, S.M.; Alexander, J.J.; Tully, J.G.; London, W.T.; Wong, D.C.; Purcell, R.H. PLC/PRF/5 (Alexander) hepatoma cell line: Further characterization and studies of infectivity. Infect. Immun. 1980, 30, 607-611. [PubMed]

26. Monjardino, J.P.; Fowler, M.J.; Thomas, H.C. Defective hepatitis B virus DNA molecules detected in a stable integration pattern in a hepatoma cell line, and in induced tumours and derived cell lines. J. Gen. Virol. 1983, 64 Pt 10, 2299-2303. [CrossRef] [PubMed]

27. Sato, N.; Watanabe, S.; Miura, K.; Goka, R.; Morimoto, N.; Takaoka, Y.; Nomoto, H.; Tsukui, M.; Isoda, N.; Nagashima, S.; et al. Acute Liver Failure Caused by the Transmission of Hepatitis B Virus from the Spouse after 38 Years of Marriage. Intern. Med. 2019, 58, 2963-2968. [CrossRef] [PubMed]

28. Ogawa, M.; Kamimura, S.; Kanda, T.; Takahashi, H.; Mizutani, T.; Matsumoto, N.; Yamamoto, T.; Nirei, K.; Matsuoka, S.; Takei, M.; et al. Long-term follow-up of a Japanese patient with hepatitis B virus genotype $\mathrm{H}$ and human immunodeficiency virus coinfection. Future Virol. 2019, 14, 633-639. [CrossRef]

29. Li, N.; Zhao, L.; Guo, C.; Liu, C.; Liu, Y. Identification of a novel DNA repair-related prognostic signature predicting survival of patients with hepatocellular carcinoma. Cancer Manag. Res. 2019, 11, 7473-7484. [CrossRef] [PubMed]

30. Han, M.E.; Kim, J.Y.; Kim, G.H.; Park, S.Y.; Kim, Y.H.; Oh, S.O. SAC3D1: A novel prognostic marker in hepatocellular carcinoma. Sci. Rep. 2018, 8, 15608. [CrossRef] [PubMed]

31. Jeannot, E.; Harlé, A.; Holmes, A.; Sastre-Garau, X. Nuclear factor I X is a recurrent target for HPV16 insertions in anal carcinomas. Genes Chromosomes Cancer. 2018, 57, 638-644. [CrossRef] [PubMed]

32. Lesbats, P.; Engelman, A.N.; Cherepanov, P. Retroviral DNA Integration. Chem. Rev. 2016, 116, $12730-12757$. [CrossRef] [PubMed]

33. Bodelon, C.; Untereiner, M.E.; Machiela, M.J.; Vinokurova, S.; Wentzensen, N. Genomic characterization of viral integration sites in HPV-related cancers. Int. J. Cancer. 2016, 139, 2001-2011. [CrossRef] [PubMed]

34. Aimola, G.; Beythien, G.; Aswad, A.; Kaufer, B.B. Current understanding of human herpesvirus 6 (HHV-6) chromosomal integration. Antiviral Res. 2020, 176, 104720. [CrossRef] [PubMed]

35. Tuna, M.; Amos, C.I. Next, generation sequencing and its applications in HPV-associated cancers. Oncotarget 2017, 8, 8877-8889. [CrossRef] [PubMed]

36. Bowcock, A.M.; Pinto, M.R.; Bey, E.; Kuyl, J.M.; Dusheiko, G.M.; Bernstein, R. The PLC/PRF/5 human hepatoma cell line. II. Chromosomal assignment of hepatitis B virus integration sites. Cancer Genet. Cytogenet. 1985, 18, 19-26. [CrossRef] [PubMed]

37. Kojima, H.; Yokosuka, O.; Imazeki, F.; Saisho, H.; Omata, M. Telomerase activity and telomere length in hepatocellular carcinoma and chronic liver disease. Gastroenterology 1997, 112, 493-500. [CrossRef] [PubMed]

38. Wolosz, D.; Walczak, A.; Szparecki, G.; Dwojak, M.; Winiarska, M.; Wolinska, E.; Gornicka, B. Deleted in Liver Cancer 2 (DLC2) protein expression in hepatocellular carcinoma. Eur. J. Histochem. 2019, 63. [CrossRef] [PubMed]

39. Ching, Y.P.; Wong, C.M.; Chan, S.F.; Leung, T.H.; Ng, D.C.; Jin, D.Y.; Ng, I.O. Deleted in liver cancer (DLC) 2 encodes a RhoGAP protein with growth suppressor function and is underexpressed in hepatocellular carcinoma. J. Biol. Chem. 2003, 278, 10824-10830. [CrossRef] [PubMed]

40. Xiaorong, L.; Wei, W.; Liyuan, Q.; Kaiyan, Y. Underexpression of deleted in liver cancer 2 (DLC2) is associated with overexpression of RhoA and poor prognosis in hepatocellular carcinoma. BMC Cancer 2008, 8, 205. [CrossRef] [PubMed]

41. Zhang, H.; Wang, F.; Hu, Y. STARD13 promotes hepatocellular carcinoma apoptosis by acting as a ceRNA for Fas. Biotechnol. Lett. 2017, 39, 207-217. [CrossRef] [PubMed]

42. Wylie, T.N.; Wylie, K.M.; Herter, B.N.; Storch, G.A. Enhanced virome sequencing using targeted sequence capture. Genome Res. 2015, 25, 1910-1920. [CrossRef] [PubMed] 
43. Wylie, K.M.; Wylie, T.N.; Buller, R.; Herter, B.; Cannella, M.T.; Storch, G.A. Detection of Viruses in Clinical Samples by Use of Metagenomic Sequencing and Targeted Sequence Capture. J. Clin. Microbiol. 2018, 56, e01123-18. [CrossRef] [PubMed]

44. Kiselev, D.; Matsvay, A.; Abramov, I.; Dedkov, V.; Shipulin, G.; Khafizov, K. Current Trends in Diagnostics of Viral Infections of Unknown Etiology. Viruses 2020, 12, 211. [CrossRef] [PubMed]

45. Duan, M.; Hao, J.; Cui, S.; Worthley, D.L.; Zhang, S.; Wang, Z.; Shi, J.; Liu, L.; Wang, X.; Ke, A.; et al. Diverse modes of clonal evolution in HBV-related hepatocellular carcinoma revealed by single-cell genome sequencing. Cell Res. 2018, 28, 359-373. [CrossRef] [PubMed]

46. Brechot, C.; Pourcel, C.; Louise, A.; Rain, B.; Tiollais, P. Presence of integrated hepatitis B virus DNA sequences in cellular DNA of human hepatocellular carcinoma. Nature 1980, 286, 533-535. [CrossRef] [PubMed]

47. Dejean, A.; Brechot, C.; Tiollais, P.; Wain-Hobson, S. Characterization of integrated hepatitis B viral DNA cloned from a human hepatoma and the hepatoma-derived cell line PLC/PRF/5. Proc. Natl. Acad. Sci. USA 1983, 80, 2505-2509. [CrossRef] [PubMed]

48. Koch, S.; Freytag von Loringhoven, A.; Kahmann, R.; Hofschneider, P.H.; Koshy, R. The genetic organization of integrated hepatitis B virus DNA in the human hepatoma cell line PLC/PRF/5. Nucleic Acids Res. 1984, 12, 6871-6886. [CrossRef] [PubMed]

49. Watanabe, Y.; Yamamoto, H.; Oikawa, R.; Toyota, M.; Yamamoto, M.; Kokudo, N.; Tanaka, S.; Arii, S.; Yotsuyanagi, H.; Koike, K.; et al. DNA methylation at hepatitis B viral integrants is associated with methylation at flanking human genomic sequences. Genome Res. 2015, 25, 328-337. [CrossRef] [PubMed]

(C) 2020 by the authors. Licensee MDPI, Basel, Switzerland. This article is an open access article distributed under the terms and conditions of the Creative Commons Attribution (CC BY) license (http://creativecommons.org/licenses/by/4.0/). 